\title{
Nezapomenuté místo

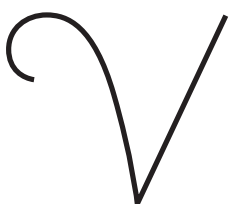 posledního spočinutí: Umění a kultura Komenského muzea v Naardenu
}

\author{
Hans van der Linde ${ }^{a}$ \\ a Památník a Muzeum J. A. Komenského \\ v Naardenu \\ info@comeniusmuseum.nl
} DOI 10.15240/tul/006/2021-2-009
Pojetí umění u Komenského

Jan Amos Komenský se zabýval rovněž uměním a uměleckou tvorbou. VeVelké didaktice (Didactica Magna) pojímá umění čistě prakticky, když konstatuje: „Je velmi jednoduché umění vnímat, ale mnohem obtížnější je umění tvořit“. Následně vysvětluje, jak by se měl student tvorbě naučit. V praxi to znamená řídit se dobrým vzorem, a až ruka a duch nasbírají zkušenosti, budou umělecká díla vznikat mnohem spontánněji. Komenského koncept zůstává prakticky orientovaný, výuka výtvarné výchovy je v něm pojímána jako osvojení dovedností. Odborník na umění je pak ten, kdo v sobě spojuje dovednosti se znalostmi.

Abychom mohli vytvořit umělecké dílo, jsou podle Komenského nutné tři předpoklady - př́ílad nebo umělcova idea, materiál a nástroje. Následující úvahy bych rád spojil s uměleckým dílem, jehož ústřední postavou je Komenský, totiž s Komenského mauzoleem v Naardenu. Mauzoleum vzniklo v letech 1933-1937 a záhy se proslavilo. Záměrem každého uměleckého díla je něco sdělit. Viděno z pohledu recipienta lze v uměleckém díle spatřit něco, co překračuje hranice materiálu, ze kterého bylo vytvořeno. $V$ případě tohoto uměleckého díla má zcela mimořádný význam jeho stanoviště: je to místo posledního spočinutí Komenského. Památník je pamětním místem, které má potenciál stát se kultem. Práce umělcova někdy nepromlouvá pouze sama za sebe, ale stává se součástí většího celku. $V$ tomto případě se jedná o světové uznání, či dokonce uctění muže, jenž je pro své spř́ízněné duše dodnes zdrojem inspirace. 


\section{Z Amsterdamu do Naardenu}

O komplikovaném, ale zároveň fascinujícím životě Komenského víme mnohé. Víme, že poslední léta strávil v Amsterdamu a že je pochován v Naardenu. Je toho však hodně, co nevíme nebo čím si nejsme jisti. Zemřel 15. listopadu 1670. Zemřel v osamění? Obával se posledního soudu, nebo o svém setkání s Hospodinem nepochyboval? Zemřel v Amsterdamu? Nebo snad v Naardenu? Z rejstř́k ku pohřbů valonské kaple v Naardenu lze vyčíst, že se pohřeb konal 22. listopadu 1670. Ale proč právě v Naardenu? Je to jedna z nejčastějších otázek, na kterou by návštěvníci rádi znali odpověd. Uvádí se více důvodů, správná odpověd’ mi však není známa. A nabízí se samozřejmě otázka další: nakolik je to vlastně vưbec dưležité? Není důležitější, že existuje místo, kde je Komenský uctěn? Po smrti jsou si před Bohem všichni rovni. Rozdíl je $\mathrm{v}$ tom, že někteří mají vlastní památník.

\section{Kde je hrob?}

V období po pohřbu Komenský vlastní památník neměl. Byl pohřben pod obyčejným náhrobkem číslo 8 . Nic mimořádného. Později se však jeho památníkem stalo Komenského mauzoleum, které si každoročně prohlédnou tisíce návštěvníků.

\section{Co se mezitím odehrálo?}

Komenského hrob nejprve upadl v zapomnění. Valonská kaple, ve které byl pohřben, zchátrala a musela být roku 1819 uzavřena. V zemích Koruny české postupně rostl zájem o Komenského. S tím souvisely snahy zjistit, co se stalo s jeho hrobem. Roku 1836 přijel do Naardenu český archeolog a spisovatel Jan Erazim Vocel, který se rozhodl najít Komenského hrob. Stará valonská kaple však už v této době byla zapomenuta. Místní obyvatelé poslali Vocela do Velkého kostela, kde se mu samozřejmě Komenského hrob najít nepodařilo. K druhému pokusu došlo roku 1870. Spolek pražských učitelů „Budeč“ chtěl připomenout výročí úmrtí Komenského a vyžádal si informace o hrobu u nizozemského ministerstva zahraničí. Výzkum v amsterdamských archivech nicméně nepřinesl výsledky, úspěch se dostavil až s telefonáty do nizozemských novin - ukázalo se, že jistý naardenský notár̆ 
má $\mathrm{k}$ dispozici rejstř́k hrobů valonské kaple. Podle tohoto zdroje byl Komenský pochován v hrobě číslo 8 . O deset let dříve však došlo k přičlenění kaple k přilehlým armádním kasárnám a k renovaci. Náhrobky byly tehdy odstraněny a předpokládalo se, že hroby byly exhumovány. Přesto neproběhl žádný další výzkum.

Roku 1892, u příležitosti třístého výročí Komenského narození, nabyl zájem o Komenského celosvětových, mezinárodních rozměrů. Oslavy výročí probíhaly také v Naardenu. Během vzpomínkové akce byla ve Velkém kostele uvedena kantáta Pocta Komenskému, vytvořená pro tuto př́ležitost. Zpívá se v ní:

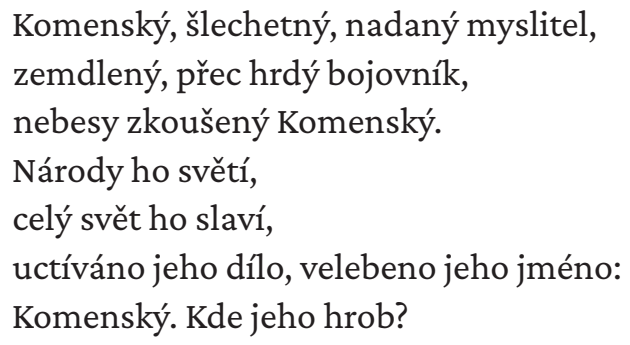

Ve víře, že jsou Komenského ostatky nenávratně ztraceny, mu byl postaven pomník. Ve snaze uctít Komenského dílo uspořádala radnice v Naardenu roku 1892 výstavu, která položila základy pozdějšího Komenského muzea v Naardenu.

Komenského kult posílilo i založení Československé republiky roku 1918. Čechoslováci žijící v Nizozemsku požádali u této příležitosti prezidenta Masaryka, aby podpořil rozšíření Komenského památníku v Naardenu. Podpora přišla roku 1920 ve formě Komenského busty od Josefa Strachovského. Od té doby se zde každoročně konala setkání, která měla památku J. A. Komenského připomínat.

Setkání se zúčastnil byl také nizozemskýlékař R. A. Oosterhuis. Pozastavoval nad tím, proč se setkání koná u Komenského pomníku, nikoli u jeho hrobu. Celou věc prověřil a roku 1924 se mu podařilo prokázat, že hroby ve skutečnosti exhumovány nebyly, a že se tedy Komenského hrob musí stále nacházet ve staré valonské kapli. Otázkou bylo pouze, 
kde přesně hrob leží, protože náhrobky s čísly byly odstraněny, takže nebylo možné zjistit, kde byl hrob číslo 8 původně situován.

Naardenský starosta nechtěl exhumací narušit věčný klid mrtvých. Na naléhání z hlavního města však souhlasil s tím, aby byl v kapli v omezeném rozsahu proveden archeologický výzkum, ovšem pod podmínkou, že ostatky nebudou převezeny do Československa. 22. července 1929 přinesly noviny zprávu o znovuobjevení hrobu J. A. Komenského.

\section{Di̊stojné místo posledního spočinutí a zázračný okamžik}

Naardenský starosta projevil nesouhlas s převozem Komenského ostatků do rodné země. Ale na druhou stranu navrhl přestavbu kasáren na mauzoleum. V letech 1930-1933 probíhaly diskuze o průběhu a stavu stavby mezi českými a nizozemskými státníky. Dne 28. 3. 1933 byla uzavřena dohoda „s cílem vytvořit pro Komenského ostatky důstojné místo posledního spočinutí“. Poté, co stavba prošla renovací, přijela do Naardenu delegace českých umělců. Jejími členy byli mj. architekt Ladislav Machoň, umělecký sklář František Kysela a sochař Jaroslav Horejc. Ti všichni byli názoru, že si výjimečná osobnost Komenského žádá, aby se interiér nesl v českém duchu. Všechny dekorativní práce tak realizovali čeští umělci a z českých materiálů. Nabídka nizozemského Výboru Komenského instalovat v muzeu vitrážové okno byla po zvážení zamítnuta. Volba nakonec padla na velkoformátové leptané skleněné panely umístěné v ocelových rámech, které pưsobí téměř tematicky - jako kapitoly z Komenského života jakožto kněze, učitele, uprchlíka, filozofa, mírotvorce a exulanta. Jaroslav Horejc vytvořil reliéfy ztvárňující významná léta Komenského života. Mladou rodinu roku 1618, smutek nad ztrátou manželky a dětí roku 1623, útěk do Polska roku 1628, cestu do Anglie roku 1641, příchod do Švédska roku 1642, pobyt ve městě Sárospatak roku 1650, vypálení Lešna roku 1656, které jej donutilo přesídlit do Amsterdamu, kde v roce 1670 zemřel. Od téhož umělce pochází také impozantní svíce s lidskýma rukama, jež se vztahují ke světlu.

Karel Štipl byl zodpovědný za mohutné dřevořezby. Celý projekt vedl architekt Ladislav Machoň. Ze záznamů víme, že Ladislav Machoň 
vytvořil model a požádal prezidenta Masaryka, aby se k němu vyjádřil. Není však známo, zda prezident model skutečně viděl.

Zajímavá je otázka, odkud umělci čerpali informace, jež se staly základem jejich umělecké práce. Do jaké míry byly tyto informace spolehlivé? Jaká fakta umělecké dílo zpracovává a co je umělcova fantazie? Byli si umělci vědomi, že jejich tvorba ovlivní názor návštěvníkư? A jaký byl umělecký záměr? Co má návštěvník vidět? Tyto informace jsem v průvodci mauzolea nenašel. Je možné, že bychom odpovědi nalezli v českých archivech.

V květnu 1937 přinesly noviny u příležitosti otevření Komenského mauzolea tuto zprávu: „Slavný památník pro ty, kdo si cení Komenského a jeho díla: pro Čechy a Holand’any, pro pedagogy a pacifisty; místo, kde mohou sklonit hlavu a uctít tak největšího Čecha“. Skutečnost, že se do realizace mauzolea promítl i český patriotismus, lze vyvodit z okna s daty 1648 a 1918 i z Komenského citátu, který parafrázoval Masaryk a později Havel: „Věřím i já Bohu, že po přejití vichřic hněvu vláda věcí tvých k tobě se zase navrátí, ó, lide český!“

Leptané skleněné panely obsahují zednářské symboly. To samozřejmě není náhoda, dưkaz spatřil světlo světa roku 2009, kdy byla objevena měděná schránka se zprávou autorů - Horejc, Štipl a Benda zde sdělují, že jsou zednáři a svou práci provedli „s láskou a úctou k velkému Učiteli národů, Janu Ámosi Komenskému, otci zednářư“.

Od roku 1992 je Komenského mauzoleum spojeno s muzeem Komenského. Jsme vděčni za podporu a spolupráci, které se nám při propagaci Komenského odkazu dostává z České republiky, především od našich kolegů z Uherského Brodu, Prahy a Přerova. My v Naardenu se snažíme přispět tím, že pravidelně pořádáme Komenského výročí. V tento den se předávají Komenského vyznamenání, prezentují se publikace, konají se přednášky a samozřejmě výstavy.

Hledali jsme nové cesty a objevili jsme možnosti umění. Setkali jsme se s řadou profesionálních umělců a nechali se inspirovat Komenského dílem a myšlenkami. V minulých letech jsme u přiležitosti výročí vydání Informatoria školy mateřské a Labyrintu světa uspořádali výstavy. Roku 2019 jsme společně s kolegy z muzea Komenského v Uherském Brodě a z památníku Lidice realizovali výstavní projekt Škola! Umění 
ze škamen. Komenský a vzdělávání očima dětí. Snažili jsme se zjistit, jak se výtvarně projevuje dětská reflexe Komenského a školního vzdělávání. A právě v tomto bodě se objevuje síla umění. Umění se určitým způsobem odlišuje od svého okolí, a tím vyniká. Všichni jednoho dne zemřeme, jen málokdo však bude mít vlastní památník. Zpráva o životě zkresluje a vyžaduje pozornost. Uměnív mauzoleu nám naopak přibližuje osobnost Komenského a význam jeho díla pro naši kulturu. Umění vyzývá a podněcuje člověka, aby přemýšlel o kultuře - o způsobu, jakým se společně snažíme náš život utvářet. Komenského názory na toto téma jsou dodnes podnětné, o čemž svědčí i to, kolik návštěvníků z různých světadílů na místo Komenského posledního spočinutí každým rokem zavítá.

Komenského v Naardenu připomíná kult mauzolea, který působí jako poutní místo. Osobně mi na tom nic nevadí pod podmínkou, že to tím nekončí, ale že se jedná o připomínku toho, v čem spočívá esence života. A rád bych v závěru tohoto př́íspěvku citoval Komenského: „Má-li se člověk stát člověkem, musí se vzdělat.“V tomto smyslu představuje Komenského mauzoleum umění, kulturu a kult zároveň.

Tento članek je publikován na počest Hanse van der Lindeho, který zemřel 24. dubna 2020. K jeho úmrtí uvedla ředitelka Národního pedagogického muzea a knihovny J. A. Komenského PhDr. Markéta Pánková tato slova: „Odešel člověk, kterého jsem si vážila hlavně proto, že se stále snažil o lepši propagaci a šírení aktuálního odkazu Komenského nejen $v$ rámci činnosti naardenského muzea. Navzájem jsme si přáli vše dobré a měli jsme oba dva radost $z$ naši vzájemné spolupráce na poli komeniologie. Bude chybět nejen mně, ale celé světové komeniologické rodině." 